International Journal of Economics, Business and Accounting Research (IJEBAR)

Peer Reviewed - International Journal

Vol-4, Issue-2, 2020 (IJEBAR)

E-ISSN: 2614-1280 P-ISSN 2622-4771

https://jurnal.stie-aas.ac.id/index.php/IJEBAR

\title{
EFFECT OF ADVERTISING MESSAGE AND CUSTOMER TRUST AND ATTITUDES CONSUMERS ON PURCHASE DECISIONS SERVICES AND COSTUMER LOYALTY IN USING SERVICES PERTAMINA HOSPITAL IN BALIKPAPAN
}

\author{
Gusti Noorlitaria Achmad 1) Rahmawati2) \\ 1,2Faculty of Economics and Business Mulawarman University \\ Email: gusti.noorlitaria.achmad@feb.unmul.ac.id rahmawati@feb.unmul.ac.id
}

\begin{abstract}
This study aims to determine the effect of the influence of advertising messages, consumer trust and consumer attitudes towards the purchase decisions services and consumer loyalty in using Pertamina Hospital services in Balikpapan. Data analysis tools used in this study are Partial Least Square (PLS) with the help of SmartPLS 3.0 software. The results of this study indicate: (1) Advertising messages have a positive and significant effect on consumer decisions, (2) Advertising messages has a positive and significant effect on Customer Loyalty, (3) Consumer Trust has a positive and significant effect on Purchase decisions, (4) Customer Trust has a positive and significant effect on Customer Loyalty, (5) Consumer Attitude has a negative and insignificant effect on Purchase decisions Services, (6) Consumer Attitude has a positive and significant influence on Customer Loyalty, (7) Decision on Using RSPB Services gives positive and significant influence on Customer loyalty.
\end{abstract}

Keywords: Advertising Message, Costumer Trust, Consumer Attitude, Purchase decisions Services, and Customer Loyalty.

\section{Introduction}

Hospital as an institution that is engaged in the field of healthy services undergo changes, at the beginning of its development, hospital is an institution that serves the social, but with the hospital of private, making hospital more refers to as an industry that is engaged in the field of services of health to carry out the management of the based on business entity management. Along with it, the case of competition between fellow hospital both hospitals belongs to the government or hospital belonged to a private, all vying to attract consumers in order to use its services.

At the time of this, hospital evolve as an industry of solid work, solid capital, and solid technology. Called thus because hospital utilize human resource management in a number of the large and diverse qualifications. Thus, also the amount of funds used to carry out various types of services, including revenue hospital. Hospital also utilize various types of technology medicine advanced to improve the quality of service. Product general industrial hospital is a service ministry of health (Muninjaya, 2011). On the side of the other hospital need to do an effort to keep survive and thrive given the magnitude of the cost of operating the hospital are very high with the increased competition the quality of care services.

Promotions hospital when it still felt " taboo " because the word sale are connoted by the sense of persuading and directing a person in order to visit the hospital certain. Yet as that already we know, promotion is one of the media that is very good when promotions are in accordance with the conditions actually hospital that, to be honest, informative, 


\section{International Journal of Economics, Business and Accounting Research (IJEBAR) Peer Reviewed - International Journal \\ Vol-4, Issue-2, 2020 (IJEBAR) \\ E-ISSN: 2614-1280 P-ISSN 2622-4771 \\ https://jurnal.stie-aas.ac.id/index.php/IJEBAR}

educational, and can make a person more clearly and understand about the ministry of health who would they get.

Internet became a media that powerful to commercialize or do promotional products - products goods or services, so that the users Internet can see, to know, to be interested to use the products or services are displayed. Hospital center Pertamina Balikpapan using media social as a means to advertise services that exist at hospital the center of Pertamina Balikpapan.

Destination marketing hospital is introducing hospital in the community area, inform clearly about the facilities and capabilities of service that is owned by hospitalness in the community and all the people hospital, shaping and fostering the image of hospital with the trust and appreciation of society against the ability of hospitalness, utilization of resources southwest hospital is optimal and besides it was hospital also expect the increase in earnings. However, the management of marketing is not to be applied is free in the field of hospitalness, especially in applying the promotion. There are restrictions or ethics that must be obeyed as the ethical promotion of hospitalness.

Confidence against the officer of health at Hospital is one of the factors of trust towards hospital in general. According to Susilowati (2011) trust is an important point for a nurse. Care nursing that good when it can be measured through the trust that was given by the community. Society has been able to assess the standard of practice that given the nurse, then ethics and professionalism. If the standard is not met, then the community no longer believes.

According to Morgan and Hunt (2008) aspects of trust in the ministry of health in Hospital is the level of confidence of patients to the ability of the home ill to meet the expectations of the patient or the extent to which the patient believes to expertise that owned the hospital. It it can be demonstrated by the confidence of patients to the credibility of the Hospital, guarantee service as well as the intention either of the parties Hospital.

The objectives of this research is to find out effect of advertising message on purchase decisions, effect of advertising message on customer loyalty, effect of customer trust on purchase decisions, effect of customer trust on customer loyalty, effect of customer attitude on purchase decisions, effect of customer attitude on customer loyalty, and effect of purchase decisions on customer loyalty.

\section{Literature Review Advertising message}

According to Peter and Olson (2000: 181), the ad is intended to influence the affective and cognitive consumers - evaluation, feelings, knowledge, meanings, beliefs, attitudes, and the image that is associated with the product and the brand. Although the first ad will affect affection and cognition, the goal most end is how to influence the behavior of purchasing consumer.

From the definition above can be concluded that the message the ad is an effort that is made by the company to convey the meaning of a product so that the consumer can understand about the product which is then expected consumers will be attracted to a product.

According to the Judge (2006: 49) the advertising message indicator can be described as follows:

1. Simple

2. Unexpected

3. Persuasive 
International Journal of Economics, Business and Accounting Research (IJEBAR)

Peer Reviewed - International Journal

Vol-4, Issue-2, 2020 (IJEBAR)

E-ISSN: 2614-1280 P-ISSN 2622-4771

https://jurnal.stie-aas.ac.id/index.php/IJEBAR

\section{Entertaining \\ 5. Relevant \\ 6. Acceptable}

\section{Customer Trust}

Barnes (2003: 148) trust is the belief that someone would discover what that he wanted the self of others, and not anything that he had feared. Belief involves the willingness of a person to behave behavior specific for the belief that his partner will give you the satisfaction that he expected and a hope that is generally owned by someone that word, promise, or statement other people can be trusted.

Marketing people are interested in the beliefs that someone formulates about certain products and services, because trust compiles a product's image that influences buying behavior. If this trust is wrong and prevents buying, marketing people will issue advertisements to correct that trust (Sunarto, 2004: 107).

The trust indicators cited from Kim et al. In Adi (2012) research are as follows:

1. Satisfaction Guarantee.

2. Attention.

3. Candor.

\section{Costumer Attitude}

Attitude is the evaluation in a time long about who liked or did not like someone, feeling emotional and tendency to act against some object or idea (Kotler and Keller, 2009: 186).

Attitude is the tendency that is studied in behaving in a way that is fun or not fun to an object- specific (Schiffman and Kanuk, 2000: 222). Individuals will take a stance to give a variety of responses and actions about the effect that has been given the right by an object- specific.

Indicators attitude of consumers that used in research this is the model of attitude by Schiffman and Kanuk (2004: 225) that in the attitude there are three components, namely:

1. Cognitive Components

2. Affective Components

3. Conative component

\section{Purchase decisions}

The behavior of the purchase of consumer is the behavior of the purchase of the end of the consumer, both individual as well as home household who buy goods and services for consumption of private (Kotler and Armstrong, 2008: 158).

There are three processes to carry out decisions which are used as an indicator of research according to Aaker (2008: 225) decision of buying consumer has the indicator as follows:

1. buying stability

2. consideration in buying

3. appropriateness of attributes with wants and needs

\section{Costumer Loyalty}

Olson (2006: 99) Costumer loyalty are impulse behavior to perform the purchase is repetitive and to build the loyalty of customers towards a product or service that is offered by the company and to build the loyalty of customers towards a product / service that is 
International Journal of Economics, Business and Accounting Research (IJEBAR)

Peer Reviewed - International Journal

Vol-4, Issue-2, 2020 (IJEBAR)

E-ISSN: 2614-1280 P-ISSN 2622-4771

https://jurnal.stie-aas.ac.id/index.php/IJEBAR

produced by the agency business that requires time that old through a process of purchasing the repeatedly mentioned.

Kotler and Keller (2009: 138) defines loyalty as a commitment that held strong to buy again or subscribe more products or services specified in the future even though there effect situation and business marketing that has the potential to cause switching behavior.

Consumer Loyalty according to Timm $(2001,6: 7)$, states that Consumer Loyalty is an arrangement of 5 (five) elements, namely;

1. Overall customer satisfaction,

2. Customer commitment

3. The desire to become a repeat buyer.

4. The desire of customers to recommend the company to others.

5. Power hold customers to switch to a competitor.

\section{Effect of Adveertising Message on Purchase decisions}

According Sumartono (2002: 14), the message advertising is what the planned company to be delivered in its advertising and how to plan the delivery of messages that are verbal and non-verbal. Research which conducted Chukwu et al. (2019 and Haider \& Shakib (2017) explains that message advertising effect against to the decision of purchase. Based on the theoretical study and the results of empirical studies it can be arranged second allegation or $\mathrm{H} 1$ is:

H1: Advertising messages have a positive and significant effect on Purchase decision

\section{Effect of Advertising Message on Costumer loyalty}

According to Peter and Olson (2000: 181), the ad is intended to influence the affective and cognitive consumers - evaluation, feelings, knowledge, meanings, beliefs, attitudes, and the image that is associated with the product and the brand. Research which conducted Hidalgo \& Wasesa (2009) and Owomoyela et al. (2013) explains that message advertising an effect on the loyalty of consumers. Based on the results of research studies empirical then be prepared $\mathrm{H} 2$ in the research of this are:

H2: Advertising messages have a positive and significant effect on costumer loyalty.

\section{Effect of Customer Trust on Purchase decisions}

Barnes (2003: 148) trust is the belief that someone would discover what that he wanted the self of others, and not anything that he had feared. Research which conducted Dewi et al. (2013) and Permatasari (2016) explains that the confidence of consumers influence on Kepu decision- using services. Based on the results of the empirical study, the $\mathrm{H} 3$ can be arranged in this study are:

H3: Costumer Trust has a positive and significant effect on purchasing decisions.

\section{Effect of Customer Trust on Costumer loyalty}

Mowen \& Minor (2002: 312) trust the consumer is all the knowledge that is owned by the consumer and all conclusions are made consumers about the objects, attributes and benefits. Research which carried Yi-Chun Ou et al. (2013), and Mutammam et al. (2009) explains that the confidence of consumers influence on the loyalty of consumers. Based on the results of an empirical study, the $\mathrm{H} 4$ can be arranged in this study are:

H4: Costumer trust has a positive and significant effect on costumer loyalty.

Effect of Costumer Attitudes on Purchase decision 
International Journal of Economics, Business and Accounting Research (IJEBAR)

Peer Reviewed - International Journal

Vol-4, Issue-2, 2020 (IJEBAR)

E-ISSN: 2614-1280 P-ISSN 2622-4771

https://jurnal.stie-aas.ac.id/index.php/IJEBAR

Simamora (2004: 152) Attitude is the most important concept in the study of consumer behavior, by influencing consumer attitudes marketers hope to influence consumer buying behavior. Research which conducted Warayuanti \& Suyanto (2015) and Mubarok (2018) explains that the attitude of consumers influence on the decision of purchase. Based on the results of an empirical study, the H5 can be compiled in this study are:

H5: Attitudes of consumers affect positively and significantly to the Purchase decision.

\section{Effect of Costumer Attitudes on Consumer Loyalty}

Soeleman (2005: 115) in the attitude contained an assessment of emotional which can be like, not love, happy, sad, hate. Research which conducted Akbar \& James (2012) and Bagram \& Khan (2012) explains that the attitude of consumers influence on the loyalty of purchase. Based on the results of the empirical study it can be arranged H6 in this study are:

\section{H6: Costumer attitudes have a positive and significant effect on costumer loyalty.}

\section{Effect of Purchase Decision on Costumer loyalty}

Kotler \& Armstrong (2008: 158) the behavior of the purchase of consumer is the behavior of the purchase of the end of the consumer, both individual as well as home household who buy goods and services for consumption private. Research which conducted Krisnawati \& Mahmud (2017) and Santoso \& Samboro (2017) explains that the decision of buying an effect on the loyalty of consumers. Based on the results of an empirical study, the $\mathrm{H} 7$ can be arranged in this study are:

H7: Purchase decisions services has a positive and significant effect on consumer loyalty .

Based on the development of hypotheses that have been made, the conceptual framework can be arranged as follows :

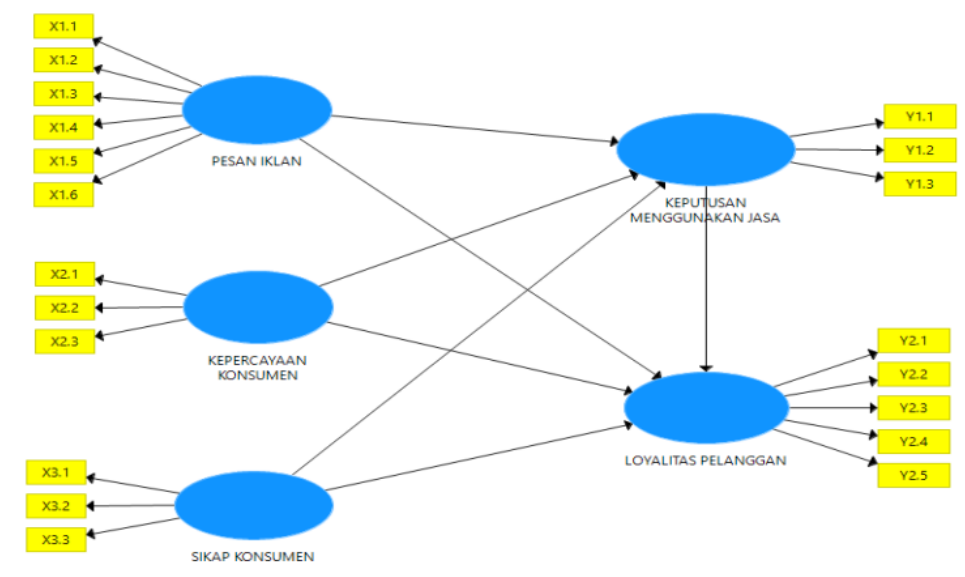

Image: Framework Concepts

\section{Research Method}


International Journal of Economics, Business and Accounting Research (IJEBAR)

Peer Reviewed - International Journal

Vol-4, Issue-2, 2020 (IJEBAR)

E-ISSN: 2614-1280 P-ISSN 2622-4771

https://jurnal.stie-aas.ac.id/index.php/IJEBAR

Population is a collection of individuals or objects that have quality and characteristics that have been determined. The population in this study are customers of the Hospital and population number is unknown. (Sugiyono, 2013: 202)

Understanding the sample is part of the number and characteristics of which are owned by the population of the samples were taken from the population that should be truly representative (represent). In determining the sample size according to Ferdinand (2014: 173) the size of the sample is determined as much as 5 times the number of indicator variables to be analyzed, where in this study there are 20 indicator variables, then: 5 x 20 $=100$.

\section{Results and Conclusion}

The construct of the validity of that kind required value AVE should be above 0.50 . In the Average Variance Extracted table shows the AVE value above 0.50 means that the variable instrument is said to be valid discriminant .

Average Variance Extracted table

\begin{tabular}{|l|l|l|l|l|}
\hline & AVE & Information & $\begin{array}{l}\text { Root Root } \\
\text { AVE }\end{array}$ & Information \\
\hline Advertising message & 0,520 & Valid & 0,721 & Valid \\
\hline Customer trust & 0,624 & Valid & 0.789 & Valid \\
\hline Consumer Attitude & 0.611 & Valid & 0.781 & Valid \\
\hline $\begin{array}{l}\text { Purchase decisions } \\
\text { Services }\end{array}$ & 0,676 & Valid & 0,822 & Valid \\
\hline Consumer Loyalty & 0,539 & Valid & 0,734 & Valid \\
\hline
\end{tabular}

\section{Composite reliability}

Reliable construct if the composite reliability value is above 0.70 . The output shows the entire construct on a variable -free and bound reliable because the values of composite reliability $>0.70$, with all publicly tables as follows :

\section{Cronbach alpha table}

\begin{tabular}{|c|c|c|}
\hline & Cronbachs Alpha & Information \\
\hline Advertising message & 0,715 & Reliable \\
\hline Customer trust & 0,726 & Reliable \\
\hline Consumer Attitude & 0,688 & Reliable \\
\hline Purchase decisions Services & 0,676 & Reliable \\
\hline Consumer Loyalty & 0,680 & Reliable \\
\hline
\end{tabular}

\section{Composite Reliability table}

\begin{tabular}{|l|c|c|}
\hline & Composite Reliability & Information \\
\hline Advertising message & 0,806 & Reliable \\
\hline Customer trust & 0,832 & Reliable \\
\hline Consumer Attitude & 0.823 & Reliable \\
\hline
\end{tabular}


International Journal of Economics, Business and Accounting Research (IJEBAR)

Peer Reviewed - International Journal

Vol-4, Issue-2, 2020 (IJEBAR)

E-ISSN: 2614-1280 P-ISSN 2622-4771

https://jurnal.stie-aas.ac.id/index.php/IJEBAR

\begin{tabular}{|l|l|l|}
\hline Purchase decisions Services & 0,813 & Reliable \\
\hline Consumer Loyalty & 0,792 & Reliable \\
\hline
\end{tabular}

\section{Estimated Structural Model (Inner Model)}

\section{a) Goodness of Fit Model}

Examination of the model can be seen from the value of R2 ( $R$-square ). This means that the model can explain the phenomenon or variations in customer satisfaction and customer loyalty can be explained by experiential marketing and customer value as for the structural model in this study as follows :

R-square table

\begin{tabular}{|l|l|l|l|}
\hline No. & Variable & R Square & R Square Adjusted \\
\hline 1 & Purchase decisions Services & .477 & 0.464 \\
\hline 2 & Consumer Loyalty & .666 & 0.654 \\
\hline
\end{tabular}

Based on the table it can be known that the Purchase decisions Services has a value of R-square of 0.477 which means Decisions Using the services can be explained by the Message Advertising and Confidence Consumer and attitude of consumers by $47.7 \%$. While the other $52.3 \%$ is explained by other variables outside the study. Furthermore, Consumer Loyalty has an R-square value of 0.666 , which means Consumer Loyalty can be explained by the Advertising Message, Consumer Trust, and Consumer Attitude and the Purchase decisions Services by $66.6 \%$. While the other $33.4 \%$ is explained by other variables outside the study.

\section{Hypothesis testing}

In the smart PLS 3.0 program to find out whether a relationship has a significant effect or not is to review the T-Statistic value with an error tolerance value of 5\%. The relationship is said to be significant if niilai T-Statistic $>1.96$, or can also through the Pvalue with the value must be $<0.05$.

The results of testing the hypothesis can be seen in the table below is:

\section{Total effect table}

\begin{tabular}{|c|c|c|c|c|c|}
\hline & $\begin{array}{l}\text { Original } \\
\text { Sample }\end{array}$ & $\begin{array}{l}\text { Sample } \\
\text { Mean }\end{array}$ & $\begin{array}{l}\text { Standard } \\
\text { Deviation }\end{array}$ & $\begin{array}{l}\text { T- } \\
\text { Statistics }\end{array}$ & P Values \\
\hline $\begin{array}{l}\mathrm{X} 1 \quad \text { Advertisement } \\
\text { Message } \\
->\quad \text { Y1 Purchase } \\
\text { decisions Services }\end{array}$ & 0,309 & 0.314 & 0.089 & 3,466 & 0.001 \\
\hline $\begin{array}{l}\text { X2 } \text { Customer trust } \\
->\quad \text { Y1 Purchase } \\
\text { decisions Services }\end{array}$ & 0.554 & 0.556 & 0.070 & 7,896 & 0,000 \\
\hline $\begin{array}{l}\text { X3 Consumer Attitude } \\
->\text { Y1The Purchase } \\
\text { decisions Services }\end{array}$ & $-0,067$ & $-0,064$ & 0.074 & 0.913 & 0.362 \\
\hline $\begin{array}{l}\text { X1 Order Advertising } \\
->\quad Y \quad 2 \text { Consumer } \\
\text { Loyalty }\end{array}$ & .243 & .241 & .106 & 2,296 & 0.022 \\
\hline
\end{tabular}


International Journal of Economics, Business and Accounting Research (IJEBAR)

Peer Reviewed - International Journal

Vol-4, Issue-2, 2020 (IJEBAR)

E-ISSN: 2614-1280 P-ISSN 2622-4771

https://jurnal.stie-aas.ac.id/index.php/IJEBAR

\begin{tabular}{|l|l|l|l|l|l|}
\hline $\begin{array}{l}\text { X 2 Customer trust } \\
->\quad \text { Y Consumer } \\
\text { Loyalty }\end{array}$ & 0.410 & 0.411 & .107 & 3,828 & 0,000 \\
\hline $\begin{array}{l}\text { X3 Consumer } \\
\text { Attitudes } \\
->\quad \text { Y2 Consumer }\end{array}$ & .186 & .185 & .974 & 3,398 & 0.001 \\
Loyalty & & .289 & 0.080 & 3,695 & 0,000 \\
\hline $\begin{array}{l}\text { Y1 Purchase decisions } \\
\text { Services } \\
->\quad \text { Y2 Consumer } \\
\text { Loyalty }\end{array}$ & 0.295 & & & & \\
\hline
\end{tabular}

H1: Message Advertising gives the effect of the positive that is at 0.309 against the Purchase decisions Services, meaning that more and better Message Ads are perceived customer is getting better or higher Purchase decisions Services. T-statistics value of 3,466 (>1.96) which means that the relationship between advertising messages and the purchase decisions services is significant. Hypothesis 1 is accepted.

$\mathrm{H} 2$ : Message Advertising gives the effect of the positive that is at 0,243 against the costumer loyalty, it means getting better Message Ads are felt by customers increasingly high level of costumer loyalty with value T-statistics amounted to 2.296 (> 1.96), means the relationship Message rent significantly to the Costumer loyalty is significant. Hypothesis 2 is accepted

H3: Trust Consumer give the effect of the positive that is at 0.554 against the Purchase decisions Services, meaning that more and better confidence Consumers are perceived customer then will be increasingly high Purchase decisions Services Hospital. The tstatistic value is significant to the Purchase decisions Services, where the Purchase decisions Services with a T-statistics value of $7.896(<1.96)$, which means a significant relationship to the Purchase decisions Services. Hypothesis 3 is accepted.

H4: Confidence Consumer give the effect of the positive that is at 0.410 against the Costumer loyalty, meaning that the more high- confidence Consumers who felt customers increasingly high level of costumer loyalty with a value of T statistic of 3.828 (> 1.96), means the relationship Confidence Consumer significantly towards Costumer loyalty. Hypothesis 4 is accepted

H5: Attitude of Consumer give the effect of the negative that is at -0.067 on the Purchase decisions Services, and are not significant to the Purchase decisions Services. That is attitude Consumers Not that provide influence positively on the Purchase decisions Services with the value of T-statistics amounted to $0.913(<1.96)$, which means that the relationship is not significant to the Purchase decisions Services. Hypothesis 5 is rejected

H6: Attitudes Consumer give effect positive that amounted to 0.186, meaning that if the attitude of consumers is getting better it will affect getting good costumer loyalty with indigo t- statistic of 3.398 (> 1.96) relationship significantly. Hypothesis 6 is accepted.

H7: Purchase decisions Services provide influence positively, namely by 0.295 , meaning that the more high- decision using the services of the increasingly high also the level of loyalty of consumers. The t- statistic value of 3,695 (> 1.96) means that the relationship 
International Journal of Economics, Business and Accounting Research (IJEBAR)

Peer Reviewed - International Journal

Vol-4, Issue-2, 2020 (IJEBAR)

E-ISSN: 2614-1280 P-ISSN 2622-4771

https://jurnal.stie-aas.ac.id/index.php/IJEBAR

between the purchase decisions services and Consumer Loyalty is significant. Hypothesis 7 is accepted

\section{Conclusion}

1. Advertising messages have a positive and significant effect on consumer decisions. Meaningful Hospital has been able to give the value of services that they offer to their customers. Hospital to be able to continue to maintain provide a value that is desirable customers and seeks to carry out an increase in the service which is able to maintain a Message Advertising in the perception of customers.

2. Advertising messages have a positive and significant effect on Consumer Loyalty. Meaningful Hospital has been able to give the value of services that they offer to their customers so that is able to make the customer to loyal use of the services of the RSPB. Hospital to be able to continue to defend giving Message Ads that wants its customers to maintain the level of Loyalty Consumer.

3. Customer trust influence positively and significantly to the satisfaction of consumers. Hospital should be able to maintain the experience that is gained customers in using the services of Hospital. Customer trust is one of the factors that is very important in shaping Purchase decisions Services. Hospital should be able to provide the experience positively on its customers thus able to maintain and get responses Customer Trust corresponding perception of the customer.

4. Customer trust has a positive and significant effect on Consumer Loyalty. Hospital should be able to maintain the trust that is gained customers that will remain loyal to use services of the RSPB.

5. Attitudes Consumer give the effect of negative and not significant to the Purchase decisions Services hospital, it means increased or whether the perception of the customer against the purchase decisions the services Hospital has not been able to improve the purchase decisions the services RSPB.

6. Attitudes Consumers give influence positively and significantly to the Loyalty Consumer RSPB, meaning customer perception going attitude can give the effect of loyalty to the RSPB.

7. Purchase decisions Services RSPB provide influence positively and significantly to the Costumer loyalty to the Hospital, meaning that the hospital has managed to make the consumers they become loyal.

\section{Suggestion}

1. Hospital to be able to continue to defend giving Message Ads are desirable customers and seeks to carry out an increase in the service which is able to maintain and continue to seek to provide information through the Message rent is up to date.

2. Hospital to be able to continue to defend giving Message Ads that wants its customers to maintain the level of Loyalty Consumer.

3. Confidence Consumers are obtained in deciding Using Services RSPB should be continuously maintained and working to always look for the information of what course to consumers to increase the confidence of the

4. Hospital should be able to generate attitude Consumers are good or positive to be able to maintain the level of costumer loyalty to use services of the RSPB.

5. Hospital should be able to generate attitude Consumers are good or positive to be able to obtain the value of positives in the perception of consumers. Trying to gather information that can improve consumer attitudes in deciding to use RSPB services. 
International Journal of Economics, Business and Accounting Research (IJEBAR)

Peer Reviewed - International Journal

Vol-4, Issue-2, 2020 (IJEBAR)

E-ISSN: 2614-1280 P-ISSN 2622-4771

https://jurnal.stie-aas.ac.id/index.php/IJEBAR

6. Hospital should be able to generate attitude Consumers are good or positive to be able to maintain the level of Loyalty Consumer RSPB without a doubt.

7. Consumers' purchase decisions RSPB services must be maintained to be able to always make their customers loyal to the RSPB.

\section{References}

Andajani, E. (2015). Understanding Kepercayaan Konsumen Management in Retailing. Procedia - Social and Behavioral Sciences, 211(September), 629633.https://doi.org/10.1016/j.sbspro.2015.11.082

Arikunto, S. (2013). Manajemen Penelitian (12th ed.). Rineka Cipta.

Brakus, J., Schmitt, B. H., \& Zarantonell o, L. (2009). Brand Experience : What Is It? How Is It Measured ? Does It Affect Loyalty? Journal of Marketing, 73(May), 52-68.

Butz, H. E., \& Goodstein, L. D. (2003). Measuring Pesan Iklan: Gaining the strategic advantage. Organizational Dynamics, 24(3), 63-77. https://doi.org/10.1016/s00902616(96)90006-6

Chandara, S. (2014). The Impact Of Customer Satisfaction And Loyalty Of Ciputra World Surabaya

Dharma, R. (2017). Pengaruh Kualitas Pelayanan, Kepercayaan, Dan Kepuasan Terhadap Loyalitas Konsumen Pada Pt. Padang Tour Wisata Pulau Padang. Jurnal EKOBISTEK Fakultas Ekonomi, 6(2), 349-359.

Ferrinadewi, E. (2008). Merek \& psikologi pelanggan: implikasi pada strategi pemasaran. Yogyakarta: Graha Ilmu.

Gentile, C., Spiller, N., \& Noci, G. (2007). How to Sustain the Kepercayaan Konsumen: European Management Journal, 25(5), 395-410. https://doi.org/10.1016/j.emj.2007.08.005

Ghozali, I., \& Latan, H. (2014). Partial Least Square: Konsep, Metode \& Aplikasi Menggunakan Program Warppls 4.0 (2nd ed.). Undip.

Griffin, E. (2011). A First Look At Communication Theory (8th ed.). Mc-Graw Hill.

Hasan, A. (2013). Marketing Dan Kasus-Kasus Pilihan. yogyakarta: CAPS.

Holbrook, M. B. (2006). Consumption experience, Pesan Iklan, and subjective personal introspection: An illustrative photographic essay. Journal of Business Research, 59(6), 714-725. https://doi.org/10.1016/j.jbusres.2006.01.008

Hurriyati, R. (2015). Bauran Pemasaran Dan Loyalitas Konsumen (4th Ed.). ALFABETA CV.

Jansen, B. J., \& Zhang, M. (2009). Twitter Power: Tweets as Electronic Word of Mouth. Journal Of The American Society For Information Science And Technology, 60(11), 2169-2188. https://doi.org/10.1002/asi

Jogiyanto. (2011). Metologi Penelitian Bisnis. (Bpfe-Yogyakarta, Ed.) (4th Ed.). BpfeYogyakarta.

Kotler, P., \& Keller, kevin lane. (2009). Manajemen Pemasaran. (J. Purba, Ed.) (12th ed.). PT.indeks.

Lapierre, J. (2005). Emerald Article: Customer-perceived value in industrial contexts Customer-perceived value in industrial contexts. Journal of Business \& Industrial Marketing, 15(2), 122-145. Retrieved from http://dx.doi.org/10.1108/08858620010316831 
International Journal of Economics, Business and Accounting Research (IJEBAR)

Peer Reviewed - International Journal

Vol-4, Issue-2, 2020 (IJEBAR)

E-ISSN: 2614-1280 P-ISSN 2622-4771

https://jurnal.stie-aas.ac.id/index.php/IJEBAR

Mahkota, A. P., Suyadi, I., \& Riyadi. (2014). Pengaruh Kepercayaan Dan Kenyamanan Terhadap Keputusan Pembelian Online ( Studi Pada Pelanggan Website Ride Inc ). Jurnal Administrasi Bisnis, 8(2).

Malik, F., Yaqoob, S., \& Aslam, A. S. (2012). The Impact Of Price Perception, Service Quality, And Brand Image On Customer Loyalty (Study Of Hospitality Industry In Pakistan). Interdisciplinary Journal of Contemporary Research in Business, 4(5), 487-506.

Marknesis, T. (2009). Pemasaran Startegi, Taktik Dan Kasus (1st ed.). yogyakarta: karangwuru.

Mujiharjo, B. (2006). Analisis Faktor-Faktor Yang Mempengaruhi Keputusan Menggunakan Jasa Dan Pengaruhnya Terhadap Loyalitas Konsumen (studi pada bank bri demak). Jurnal Sains Pemasaran Indonesia, 5(2), 193-210.

Noor, J. (2011). Metodologi Penelitian: Skripsi, Tesis, Disertasi, \& Karya Ilmiah. prenada media group.

Sam, F. M. M., \& Tahir, nor hayati. (2010). The Awareness and the Acceptance of Islamic pawnshops. Ijrras, 2(February), 117-125.

Sánchez-Fernández, R., \& Iniesta-Bonillo, M. Á. (2009). Efficiency and quality as economic dimensions of perceived value: Conceptualization, measurement, and effect on satisfaction. Journal of Retailing and Consumer Services, 16(6), 425-433. https://doi.org/10.1016/j.jretconser.2009.06.003

Sangadji, etta mamang, \& Sopiah. (2013). Perilaku pelanggan: pendekatan praktis disertai himpunan jurnal penelitian. yogyakarta: Andi.

Santoso, S. (2002). SPSS Statistik Multivariat. jakarta: PT Elex Media Komputinso Kelompok Gramedia.

Sari, D., \& Helmi, A. (2013). the Relationship Between the Pesan Iklan and Satisfaction To Advocacy Behavior: the Empirical Study in Higher Education. VSRD International Journal of Business and Management Research, 3(8), 303-310.

Schiffman, L., \& Kanuk, leslie lazar. (2004). Consumer Behavior (8th ed.).

Schmitt, B. (2011). Experience Marketing: Concepts, Frameworks and Consumer Insights. Foundations and Trends ${ }^{\circledR}$ in Marketing, 5(2), 55-112. https://doi.org/10.1561/1700000027

Senjaya, V., Samuel, H., \& Dhamaryanti, D. (2013). Pengaruh Kepercayaan Konsumen Quality Terhadap Customer Satisfaction \& Customer Loyalty Di Kafe Excelso Tunjungan Plaza Surabaya: Perspektif B2c. Jurnal Manajemen Pemasaran Petra, $1(1), 1-15$.

Steviani, A., \& Semuel, H. (2015). Pengaruh Pesan Iklan Terhadap Loyalitas Konsumen Dengan Customer Satisfaction Sebagai Variabel Intervening Terhadap Salon Shinjuku. Jurnal Manajemen Pemasaran Petra, 1(1), 1-11.

Sugiyono. (2013). Statistika Untuk Penelitian (23rd Ed.). CV ALFABETA.

Supranto. (2004). Analisis Multivariat Arti \& Interpretasi (1 st ed.). PT rineka cipta.

Suryani, T. (2008). Perilaku Pelanggan implikasi pada strategi pemasaran. Erlangga (1st ed.). yogyakarta: Graha Ilmu. Retrieved from http://library.um.ac.id/freecontents/index.php/buku/detail/perilaku-pelanggan-jilid-2-john-c-mowen-andmichael-minor-alih-bahasa-dwi-kartika-yahya-30481.html

Teas, R. K., \& Samjeev, A. (1993). The Effects of Extrinsic Product Cues on Consumers ' Perceptions of Quaiity, Sacrifice, and Vaiue. Journal of the Academy of Marketing 
International Journal of Economics, Business and Accounting Research (IJEBAR)

Peer Reviewed - International Journal

Vol-4, Issue-2, 2020 (IJEBAR)

E-ISSN: 2614-1280 P-ISSN 2622-4771

https://jurnal.stie-aas.ac.id/index.php/IJEBAR

Science, 28(2), 278-290.

Tien Tsai el al.(2010). The Effect Of Pesan Iklan, Customer Satisfaction, And Switching Cost On Customer Loyalty: An Empirical Study Of Hypermarkets In Taiwan.

Tjiptono, F. (2011). Manajemen Strategi Merek (1st ed.). CV ANDI OFFSET.

Turel, O., Serenko, A., \& Bontis, N. (2007). User acceptance of wireless short messaging services: Deconstructing perceived value. Information and Management, 44(1), 6373. https://doi.org/10.1016/j.im.2006.10.005

Umar, H. (2011). Metode Penelitian untuk Skripsi dan Tesis Bisnis (Edisi 2). rajawali pers. Verhoef, P. C., Lemon, K. N., Parasuraman, A., Roggeveen, A., Tsiros, M., \& Schlesinger, L. A. (2009). Kepercayaan Konsumen Creation: Determinants, Dynamics and Management Strategies. Journal of Retailing, 85(1), 31-41. https://doi.org/10.1016/j.jretai.2008.11.001

Wijayanti, Nurul Azizah, \& Wijaya, T. (2016). Pengaruh Loyalitas Konsumen, Kepercayaan, Dan Suasana Toko Terhadap Ewom Di Chachamilktea, 5(3), 276-286.

Woodruff, R, B. (1997). Pesan Iklan The next source for competitive advantage.pdf. Journal of the Academy of Marketing Science, 25(2), 139-153.

Zeithaml, V. A. (2006). Consumer Perceptions of Price, Quality, and Value: A Means-End Model and Synthesis of Evidence. Journal of Marketing, 52(3), 2. https://doi.org/10.2307/1251446 